\title{
EXTENSION OF THE BALANCED SCORECARD STRUCTURE FOR BANKING INDUSTRY
}

\author{
Gülșen AKMAN ${ }^{*}$, Hakan TURAN²
}
${ }^{1}$ Kocaeli Universitesi, Mühendislik Fakültesi, endüstri Mühendisliği Bölümü, Kocaeli ORCID No: https://orcid.org/0000-0002-5696-2423
${ }^{2}$ Kocaeli Universitesi, Mühendislik Fakültesi, endüstri Mühendisliği Bölümü, Kocaeli ORCID No: https://orcid.org/0000-0002-8634-3084

\begin{tabular}{ll}
\hline Keywords & Abstract \\
\hline Organizational & In today's business environment, competitive advantage is a crucial issue for \\
Performance, Balanced & companies. The Balanced Scorecard (BSC) has become prominent within recognized \\
Scorecard, Banking sector, & performance appraisal methods. Since the BSC transforms strategies to the actions, it \\
fuzzy DEMATEL, Turkey & embraces not only financial indicators but also non-financial indicators. Existing BSC \\
& containing four perspectives are not available for banks. Although the BSC is effective \\
& tool for companies, it is not dynamic and it is not sensitive to the variation. It is very \\
slow to adapt rapid changing environment. This weakness of the method could be \\
eliminated by adding risk and agile perspectives to current BSC structure. The aim of \\
this study is to propose an expanded BSC structure for banks. In order to present \\
interaction and relations of risk and agile perspectives with existing perspectives of \\
BSC, fuzzy DEMATEL method is used. The fuzzy DEMATEL results indicate that risk is \\
the most involved perspective within five perspectives.
\end{tabular}

\section{DENGELİ PUAN KARTI YAPISININ BANKACILIK SEKTÖRÜ IÇCiN GENIŞLETILMESİ}

\begin{tabular}{|c|c|}
\hline Anahtar Kelimeler & Öz \\
\hline $\begin{array}{l}\text { Organizasyonel Performans, } \\
\text { Dengeli Puan Kartı, } \\
\text { Bankacılık, bulanık } \\
\text { DEMATEL, Türkiye }\end{array}$ & 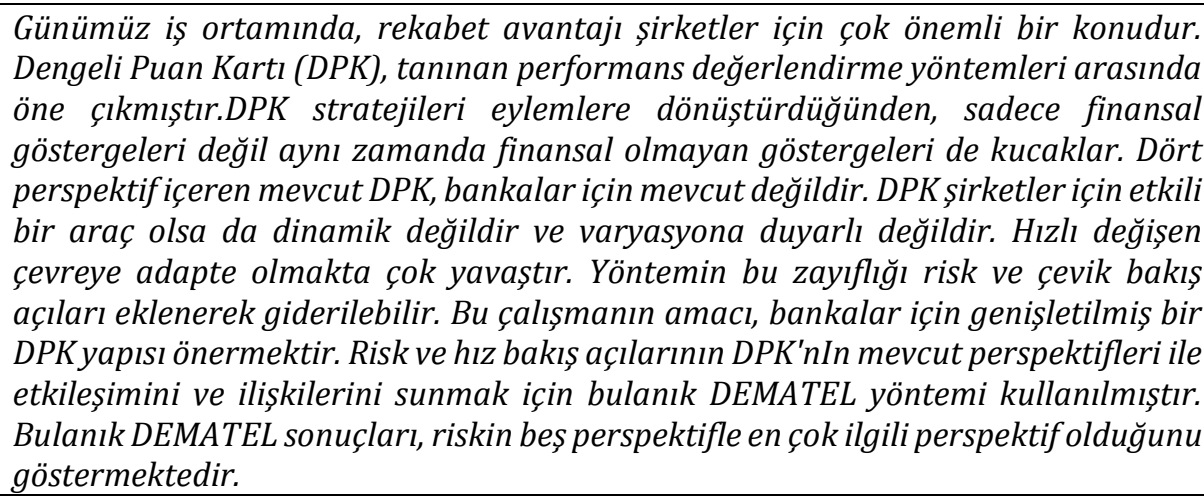 \\
\hline Araştırma Makalesi & Research Article \\
\hline Başvuru Tarihi & Submission Date \\
\hline Kabul Tarihi & Accepted Date \\
\hline
\end{tabular}

\section{Introduction}

Balanced Scorecard (BSC) depends on strategy and vision while conventional financial indicators depend on capital (Strack and Villis, 2002). BSC integrates financial and non-financial strategic indicators which are customer, internal business process, learning and growth (Kaplan and Norton, 1996). Financial perspective deals with profit and costs. Customer perspective determines the value offered to the customer who buys the product of the organization. Internal business processes focus on value added for customers and shareholders.

*Sorumlu yazar; e-posta: akmang@kocaeli.edu.tr 
Learning and growth perspective considers the future (Pettus, 2006).

There are a lot of criticism in literature regarding BSC. BSC is insufficient for firms since it does not reflect external issues. While BSC is significant in terms of internal issues, it is not effective for external parameters (Steele, Branson, and Sung, 2013; Hubbard, 2009; Nezhad, Modiri, and Yazdi, 2011). This paper examines a strategic performance structure of banks. Former conducted studies are based on that the BSC usually has four perspectives and it is insufficient to meet the needs of banks. BSC covered current productivity does not reflect new expectations since banks produce new goods and service. Agile brings about risk while new goods/service triggers agile. In order to overcome these weaknesses, the risk and agile perspectives have been added. Fuzzy DEMATEL method has been implemented in a bank to uncover the significance of perspectives and their causal relationships.

This study is constructed as following; Section 2 explains current BSC structure, and it contains literature review of the related studies using the BSC model within the banking sector. In section 3 , the methodology of the study is explained by including limitations of BSC, needs for new perspectives, proposed new BSC structure, fuzzy set theory and fuzzy DEMATEL. Section 4 presents an illustrative example in Banking sector. Section 5 includes discussions and conclusions.

\section{Literature Review}

In 1992 Kaplan and Norton introduced the idea of combining financial and non-financial (customer, internal business, and innovation and learning) perspectives in a single performance scorecard model, and they called this model as the Balanced Business Scorecard (Kaplan and Norton, 1996).

A balanced scorecard (BSC) is the most widely used tool for performance measurement BSC developed by Kaplan and Norton (1992) has been adopted as a performance management tool in all industries. BSC provides an easy and understandable standard that is suitable for organizations to achieve their goals and objectives.

Turban, Leidner, McLean, and Wetherbe (2008) defined the BSC as a method that "evaluates the overall health of organizations and projects by looking at metrics in finance, customer's view of the organization, internal business processes, and ability to change and expand".

The BSC helps managers consider their businesses from four perspectives: first, the customer perspective, which provides the answer to the question "How do customers see us?" The second perspective is the internal business perspective, which answers "What must we excel at?" The innovation and learning perspective answers "Can we continue to improve and create value?" Finally, the financial perspective answers the question "How do we look towards shareholders?" (Al-Alawi, 2018). The four perspectives of BSC which are financial, customer, internal processes and learning and growth (Kaplan and Norton, 1996) are presented in Figure 1. While the financial perspective examines data associated with to the financial situation (cash flows, profitability, and ratios) of the company, the other three perspectives focus on the company's ability to create value and mean three distinct fields of research (Oliveira, 2014). The financial perspective indicates whether a company's strategy and operations add value for shareholders. The customer perspective considers the business through the eyes of customers. This perspective indicates whether and to what extent the company meets the customers' expectations (Talathi, 2019). Internal business process perspective focuses on the performance of key internal processes which drive the organization. Learning and growth perspective considers organization's potential future performance; directing attention on the basis of all future success the organization's people and infrastructure (Talathi, 2019). While customer and learning and growth are leading perspectives, financial and internal business processes are lagging perspectives indicators. According to Pettus (2006) these lagging perspectives should enable leading perspectives (Pettus, 2006).

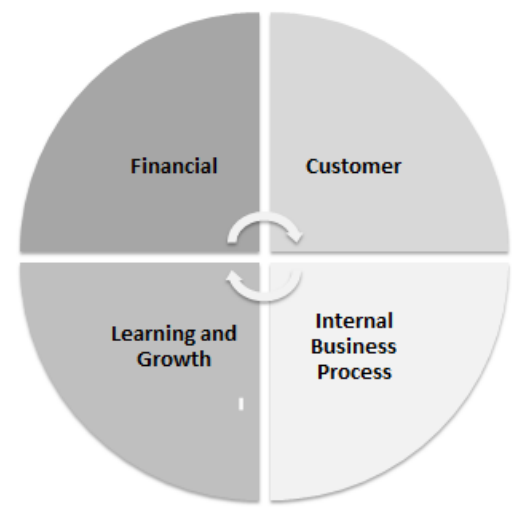

Figure 1. Current BSC perspectives 


\subsection{BSC in Banking Sector}

The BSC is a popular and widely used tool by many businesses to evaluate their performance based on different aspects of their organisation. A large amount of study associated to the banking industry has performed via the BSC approach to evaluate performance. Some prior studies are performed via BSC in Banking sector are summarized in Table 1. When these studies were investigated, it can be seen that to evaluate performance of banks, generally, the BSC consists of four perspectives in banking.

Table 1

Literature Review about application of balanced score card in banking sector

\begin{tabular}{|c|c|}
\hline Study & Content of the study \\
\hline $\begin{array}{l}\text { Dinçer and Yüksel } \\
\text { (2019) }\end{array}$ & $\begin{array}{l}\text { They used the BSC-based evaluation of the new service development in Turkish banking } \\
\text { sector. Their proposed model includes fuzzy ANP, Monte Carlo Simulation, fuzzy TOPSIS, } \\
\text { and fuzzy VIKOR respectively }\end{array}$ \\
\hline $\begin{array}{l}\text { Dinçer, Yüksel, and } \\
\text { Martínez (2019) }\end{array}$ & $\begin{array}{l}\text { They proposed a BSC based SERVQUAL approach to rank competitors in the banking sector. } \\
\text { They hesitant fuzzy information for weighting criteria and dimensions, ranking alternatives } \\
\text { and different results that will define the Turkish banking sector }\end{array}$ \\
\hline $\begin{array}{l}\text { Yllmaz and İnel } \\
(2018)\end{array}$ & $\begin{array}{l}\text { They developed a sustainability performance based BSC approach for banks in Turkey. They } \\
\text { intersected sustainability dimensions with the dimensions of the BSC (financial, customer, } \\
\text { internal processes, and learning- development dimensions). }\end{array}$ \\
\hline Owusu (2017) & $\begin{array}{l}\text { They empirically evaluated the effects of adopting BI systems on organisational } \\
\text { performance of banks. They developed a conceptual model by using the BSC via partial least } \\
\text { squares structural equation modelling for the universal banks in Ghana }\end{array}$ \\
\hline $\begin{array}{l}\text { Dinçer, Hacıoğlu, } \\
\text { and Yüksel (2016) }\end{array}$ & $\begin{array}{l}\text { They evaluated the BSC based performance of Turkish banking sector through Analytic } \\
\text { Network Process Approach in order to determine which perspectives of balanced scorecard } \\
\text { approach is appropriate for each type of banks (state banks, private banks, foreign banks) }\end{array}$ \\
\hline $\begin{array}{l}\text { Rostami, Goudarzi, } \\
\text { and Zaj (2015) }\end{array}$ & $\begin{array}{l}\text { They examined aspects of BSC and the importance of each aspect and related indicators by } \\
\text { means of Fuzzy Analytical Hierarchy Process (FAHP) is used. They found } 56 \text { indicators } \\
\text { based on prior studies and literature. Ultimately } 9 \text { indicators were extracted. }\end{array}$ \\
\hline $\begin{array}{l}\text { Alidade and Ghasemi } \\
(2015)\end{array}$ & $\begin{array}{l}\text { They used fuzzy AHP and fuzzy TOPSIS to evaluate performance of bank branches by the } \\
\text { Balanced Scorecard. Meanwhile, the Kolmogorov-Smirnov test was used to check the } \\
\text { normality of variables }\end{array}$ \\
\hline Noori (2015) & $\begin{array}{l}\text { He used an integrated approach combining BSC \& Fuzzy AHP technique to consider and } \\
\text { prioritize its strategic business units in Banking industry }\end{array}$ \\
\hline $\begin{array}{l}\text { Mandic, Delibasic, } \\
\text { Knezevic, and } \\
\text { Benkovic (2014) }\end{array}$ & $\begin{array}{l}\text { They analyzed financial parameters of Serbian banks based on BCS indicators through FAHP } \\
\text { and TOPSIS techniques. }\end{array}$ \\
\hline $\begin{array}{l}\text { Akkoç and } \\
\text { Vatansever (2013) }\end{array}$ & $\begin{array}{l}\text { They discussed the BSC indicators are discussed through FAHP and TOPSIS technique in } 12 \\
\text { Turkish banks after the financial crisis. The bank's performance evaluation is conducted by } \\
\text { the BSC }\end{array}$ \\
\hline Glykas (2013) & $\begin{array}{l}\text { He proposed a fuzzy cognitive map combining with the fuzzy logic and neural network for } \\
\text { business process performance measurement of banks }\end{array}$ \\
\hline $\begin{array}{l}\text { Dincer and Hacioglu } \\
\text { (2013) }\end{array}$ & $\begin{array}{l}\text { They analyzed the BSC model of Turkish banks based on customer satisfaction with VIKOR } \\
\text { and fuzzy AHP technique. }\end{array}$ \\
\hline $\begin{array}{l}\text { Jafari-Eskandari, } \\
\text { Roudabr, and } \\
\text { Kamfiroozi (2013) }\end{array}$ & $\begin{array}{l}\text { They investigated banks' performance evaluation model with key performance indicators } \\
\text { (KPI) based on the BSC through ANP and fuzzy DEMATEL techniques have been studied. }\end{array}$ \\
\hline
\end{tabular}


$\mathrm{Wu}(2012)$

Dave and Dave

(2012)

Aryanezhad, Njafi, and Farkoush

(2011)

Shih, Lin, and Lin (2011)

Shaverdi, Akbari, and Tafti (2011)

Rajab-Baigy, Foruzandeh, Mortazavi, Bigdeli (2011)

Sharifi and Taleghani (2011)

$\mathrm{Wu}$, Lin, and Tsai (2010)
He used DEMATEL method to link key performance indicators (KPIs) into a strategy map of BSC for banking institution Corresponding with the four BSC perspectives (finance, customer, internal business process, and learning and growth),

They evaluated the performance of Indian Banks by using BSC approach. Within this scope, the performance of State Bank of India was analyzed by using 29 performance indicators

They proposed a method to utilize BSC as a tool for designing performance evaluation indices of an organization. They applied an integrated BSC-DEA to evaluate 24 branches of a major private bank organization in İran.

They applied the methodology and structure of importance performance analysis and balanced scorecard to analyze the quality gap of all types of intellectual capital of Taiwanese banks under an integrated BSC structure.

They evaluated the performance of three nongovernmental banks in Iran by using 21 different criteria for BSC evaluated via fuzzy AHP

They designed the strategy map containing strategic goals and strategic measures in customers, internal processes, and learning and growth perspectives for Iranian Central Bank by using Delphi method and questionnaire survey

They evaluated intellectual asset performance by BSC in the Banking Industry using four dimensions of BSC.

They applied the BSC method to build a performance evaluation framework for wealth management (WM) banks in Taiwan by using Delphi method AHP and grey relational analysis (GRA).

\section{Methodology}

Methodology of the study is presented in Figure 2.

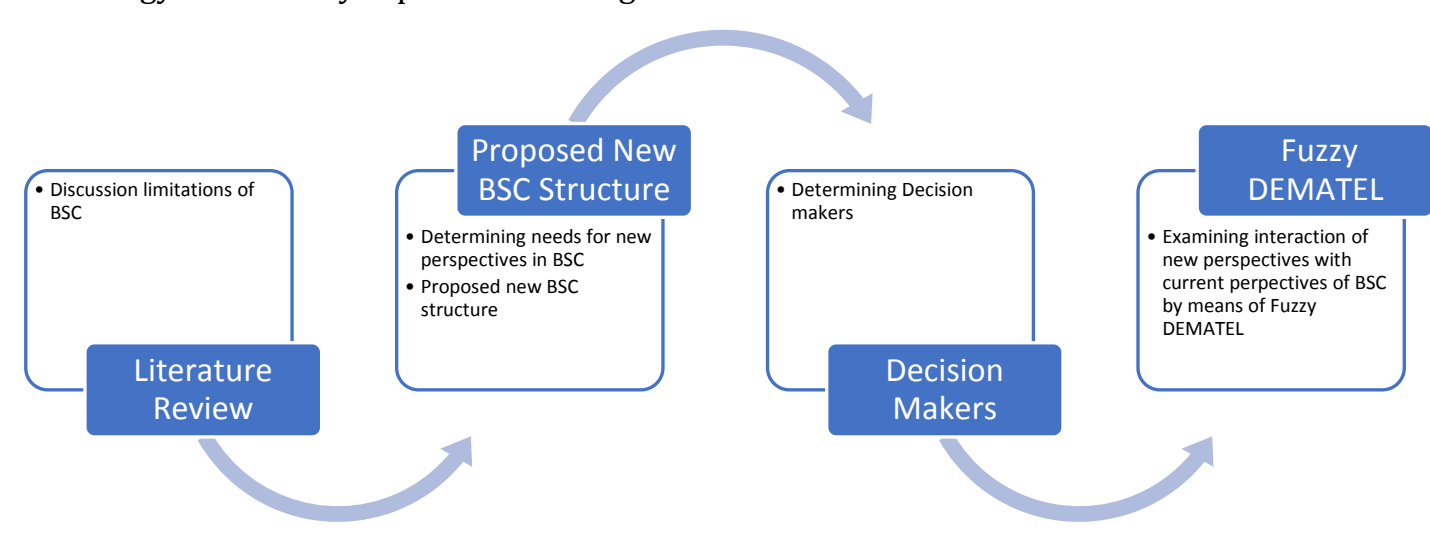

Figure 2. Methodology of the study

\subsection{Limitation of the Current BSC Model}

When literature investigated there is many criticisms regarding the insufficiency of the BSC (Rillo, 2004; Salem, Hasnan, and Osman, 2012; Awadallah and Allam, 2015)
One of these criticisms is that BSC builds its approach to analysis around only four perspectives (financial, customer, business and production processes, and learning and growth), and in fact, there may be more important perspectives than these perspectives; managerial development perspectives, social 
responsibility perspective, etc. As such, the so-called Balanced Scorecard turns into a truly unbalanced and flawed scorecard (Talathi, 2019). Because the current perspectives do not meet the needs., many perspective suggestions have been proposed in addition to the existing four BSC perspectives. Kannan, Jafarian, Khamene, and Olfat (2013) stated that BSC perspectives cover the internal environment, it does not cover the external environment, competitive performance, and stakeholder views. Möller and Schaltegger, (2005) suggest that the environmental information management system should be associated with the BSC. Wu and Haasis (2013) suggest that environmental and social perspectives should be added to the existing BSC structure. According to Nikolaou and Tsalis (2013), the BSC structure including economic, environmental and social aspects provides a more realistic performance evaluation system. Jin, Deng, Li, and Skitmore, (2013) claimed that stakeholder and market perspectives should be added to the existing BSC structure. Thompson and Mathys (2013) proposed to add the human perspective involving employees to BSC structure. It has been claimed that these deficiencies can be remedied by adding above perspectives to BSC structure. Extension of BSC should be performed according to characteristics of the company. Perspectives should be determined according to aim of the BSC and features of the company.

Another important criticism is that unlike many other strategic management and strategy analysis methods (Benchmarking, Porter 5F analysis, SWOT analysis, PEST analysis, etc.), BSC does not take into account any major interest group, but shareholders and customers. Also, no attention is paid to the daily activities of competitors. (Rillo, 2004; Salem et al. 2012). Despite the fact that BSC covers non-financial performance measurement indicators, these indicators do not include external environment ambiguities, opportunities and future changes. As mentioned in previous paragraph, the perspectives proposed to add the current BSC structure are insufficient in terms of scope. They do not serve long term plans and do not include a proactive viewpoint of opportunities and threats in external environments. Strategic planning embraces phases from current situation analysis, commonly SWOT analysis, to develop performance measurement and monitoring (Erbaşı, 2010; Demir and Yilmaz, 2010). Similarly, BSC embraces phases from vision to actions (Kaplan and Norton, 1996) excluding SWOT analysis. So, many researchers proposed that BSC must be implemented along with SWOT in numerous studies (Hajikhani and Jafari, 2013; Mahdian, Ghochani, Mahdian, and Shojaei, 2012; Penic and Dobrovic, 2013).

Since firms today that adopt a customer-based approach must be innovative, they must be agile and responsive in order to adapt to the " $O$ " phase of SWOT analysis to the existing system. Agility is the path to address opportunities presented by the external environment.

\subsection{Extension of BSC for Banking Industry}

\subsubsection{Need for Risk perspective}

A traditional BSC generally is not included key factors related to the business risks which is confronted by the company. Also, Norton and Kaplan (2008) stated that there is a gap in the BSC framework, not paying enough attention to enterprise risk management, and risk management can be used together with BSC in future. Also, they suggested that risk management metrics can definitely have a place in the financial BSC perspective to increase and maintain shareholder value, alongside traditional goals of revenue growth and efficiency improvements (Norton and Kaplan, 2008). In addition to the four perspectives of the BSC, some authors such as Beasley, Chen, Nunez, and Wright (2006) and Chen, Chen, and Peng (2008) proposed adding risk management to the BSC for financial institutions especially for banks because the banking industry faces multiple and complex operational risks, and banks confront more business risk than other industries. Tangen (2003) suggested adding the fifth perspective including operational risks which are in internal risks into the typical BSC approach. Asosheh, Nalchigar, and Jamporazmey (2010) proposed that ambiguity risks (process, human resource and technology risks) should be adopted to the existing four perspectives of the BSC. Oliviera (2014) suggest that the most critical risk 
factors should be identified according to the perspectives of BSC chosen and their indicators. Chang and Tsai (2016) used risk control factor among financial performance evaluation criteria (service, performance, professionalism, risk control, and consumers' confidence) of wealth management banks. Spano, Sarto, Caldarelli, and Viganò (2016) proposed to add risk component to internal business process perspective in the network Campania Bioscience - which operates in the field of biotechnologies and represents.

While some authors proposed that risk factors should be integrated each perspective of current BSC (Assosseh et al, 2010; Oliviera, 2014; Chang and Tsai, 2016; Spano et al., 2016), others suggest that risk factors should be defined as a separate perspective (Beasley et al., 2006; Chen et al. 2008). We proposed that risk perspective including both internal and external risks should be added as a separate perspective to current four perspectives of BSC.

\subsubsection{Need for Agile perspective}

To survive and to be competitive, companies should adapt rapidly and proactively their elements to unexpected and unpredicted environmental changes (Kidd, 1994). Companies need to be agile to provide customer-driven products and services in a fast changing environment (Rdiouat, Bahsani, Lakhdissi, and Semma, 2015). For this reason, the companies adopting a customer-oriented approach have to be innovative, and for this they must be faster than competitors, that is, transfer the "Opportunities" phase of SWOT analysis to the existing system. On the other hand, opportunity is offered by the external environment. Agility is a requirement towards achieving the opportunities in the external environment. The agile perspective is essential for a proactive management approach. Agility can also trigger risk.

The BSC is very slow to adopt the current everchanging environment of the 21st century (Askarany, 2017; Angel and Rampersad, 2005; Pickard, 2006). Ahn (2001) stated that BSC is not interested in rapid change and in extreme competition. To cope with the change, the existing BSC should be modified. Therefore, companies should adopt the philosophy of agility in order not to lose or even increase their market shares (Rdiouat et al., 2015). Agility provides to both internal and external efficiency for the companies.

Tizroo, Esmaeili, Khaksar, Šaparauskas, and Mozaffari (2017) presents the agility factors for the steel industry supply chain and are grouped these factors within the four perspectives of the BSC. They suggested that agility related factors should be integrated and adopted into four perspectives to the BSC. Also, Rdiouat et al. (2015) proposed to include agility factors into four perspectives of BSC.

In literature, it is proposed that agility factors have been integrated to current perspectives of the BSC structure. Agility perspective is not used as a separate perspective within perspectives of BSC. We proposed that agility perspective should be added as separate perspective to current BSC structure.

\subsubsection{New BSC Structure}

A new BSC structure has been suggested because of above mentioned drawbacks. In order to cope with change, current BSC must be modified. The banking sector has especially changed rapidly and affected easily financial crises and international developments. Banks should adopt to agility to increase market share and develop both external and internal efficiency for banks. But external factors are more significant than internal factors. So, the agile perspective resembles the opportunities issue of SWOT analysis. On the other hand, agility brings about risk. Risk includes both internal and external issues for banks. Risk covers external issues rather than internal issues. Similarly, risk correlates to "Threats" issues of a SWOT analysis. For this, risk and agile perspectives have been added to the current BSC structure. In addition to this, the agile perspective has been never used in past studies as separate factor in BSC structure. Our model proposes that risk and agile perspectives should be added to current BSC perspectives. New proposed BSC 
structure with six perspectives are presented in Figure 3, and their some possible sub-indicators are presented in Figure 4.

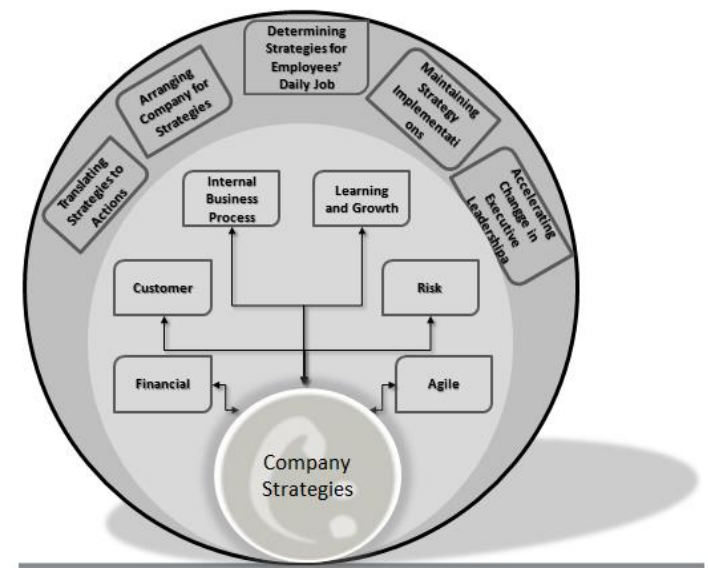

Figure 3. The proposed BSC structure

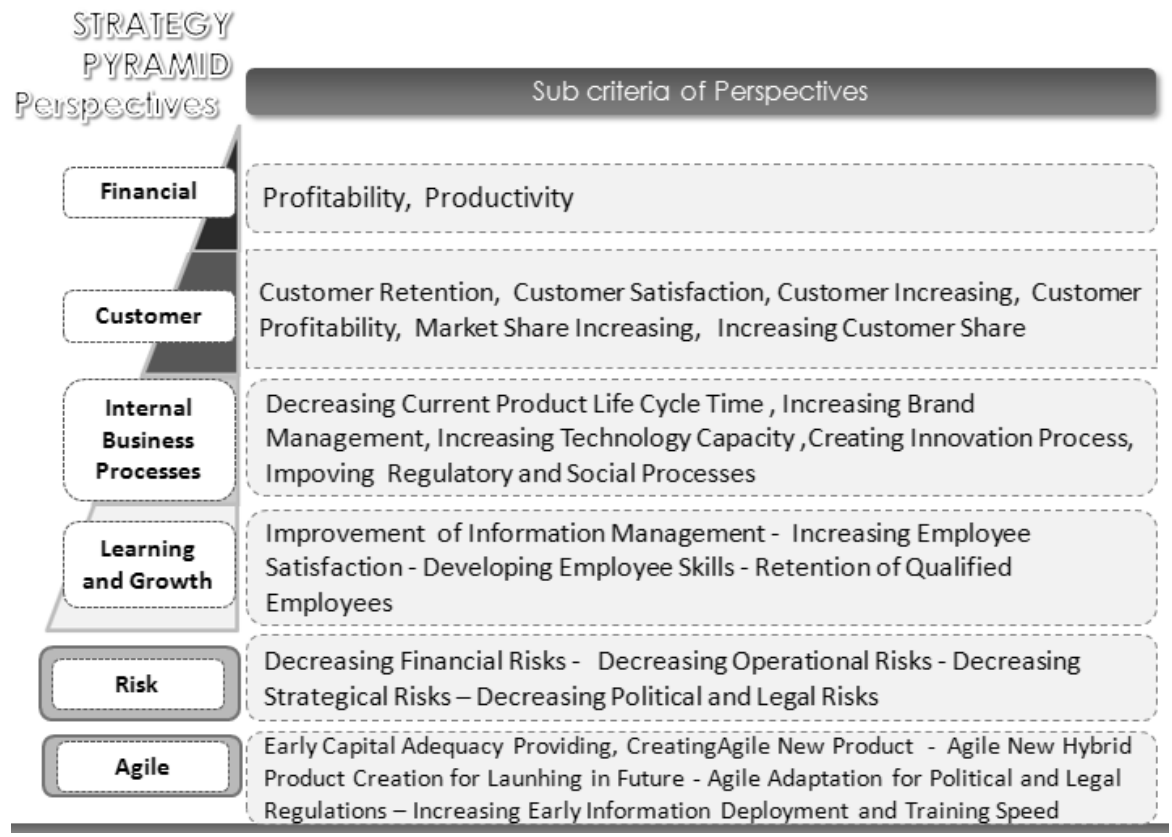

Figure 4. Perspectives and their sub criteria in proposed BSC structure

\subsection{Method}

\subsubsection{Fuzzy Set Theory}

Experts need to prefer linguistics terms rather than crisp evaluations for complex system problems. Therefore, the fuzzy set theory handles vagueness and judgments was introduced by Zadeh in 1965 (Liu, 2009). The fuzzy set theory is interested in linguistic parameter problems. Zadeh prevented the ambiguity of human judgments by the fuzzy logic (Yang, Shieh, Leu, and Tzeng 2008). The ambiguity values should be converted into the fuzzy values to eliminate the vagueness (Tseng, 2009). A fuzzy set is a class of objects with a continuum of membership degrees. Such a set is characterized by a membership (characteristic) function that assigns each object a membership degree ranging from zero to one. In the discourse universe, ? is a fuzzy set characterized by a membership function 国 (可) associated with each 
element in 0 (Jeng and Tseng, 2012). A triangular fuzzy number is presented in Figure 5. A triangular

fuzzy number ( $\tilde{A})$ is referred as ( 回 / 国, 回 / 回) or (回, [?, 目). The parameters, and, respectively, $l$ indicates the smallest possible value, $m$ indicates the most promising value and $u$ indicates the largest possible value describing a fuzzy event. Membership function $(\mu \tilde{A})$ is presented in Figure 5.

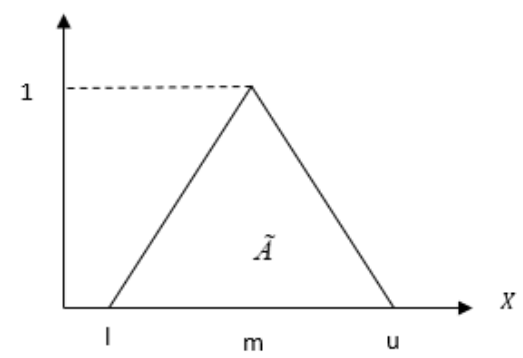

Figure 5. Membership function of triangular fuzzy number

The fuzzy membership function is identified by Equation (1)

$\mu_{x}(y)=\left\{\begin{array}{rl}0 & y<l \\ \frac{(y-a)}{(b-a)} & l \leq y \leq m \\ \frac{(u-y)}{(u-m b)} & m \leq y \leq u \\ 0 & y>u\end{array}\right.$

Multiple Criteria Decision Making (MCDM) is a technique which chooses one or one more option with multiple aims (Malekly, 2010). Fuzzy Multiple Criteria Decision Making (MCDM) is constituted by combining MCDM and fuzzy set theory (Hung, Julian, Chien, and Jin, 2010; Shieh, Wu, and Huang, 2010).

\subsubsection{Fuzzy DEMATEL}

The DEMATEL method is developed to handle complex decision problems by the Geneva Battelle Memorial Institute Science and Human Relationships Programme (Gabus and Fontela, 1972). It considers both direct effects and indirect interactions. The DEMATEL is a method that helps information gathering from groups and it enables to visualization by means of scheme (Wu and Lee, 2007; Chen and Chen, 2010). The DEMATEL outlines problems by dividing related factors into cause-effect relationship. If the criteria affect the other criteria, this is called as 'the effect factor'. On the other hand, if a criterion is affected by the other criteria, this is called as 'the cause factor' (Aksakal and Dağdeviren, 2010; Baykaşoğlu, Kaplanoğlu, Durmuşoğlu, and Şahin 2013).

Although the DEMATEL method can visualize causal relations, it is difficult to express these relations with numbers. The Fuzzy DEMATEL clarifies relationship between the cause and effect (Lee, Hu, Yen, and Tsai, 2008). The Fuzzy DEMATEL is implemented to tackle decision making problems. The phases of the fuzzy DEMATEL method are below (Aksakal and Dağdeviren, 2010).

Step 1: Determining criteria and generating fuzzy scale

Evaluation scale with linguistics terms and their fuzzy linguistic values are presented in Table 2 .

Table 2

The Linguistic Terms and Fuzzy Linguistic Values (Wu and Lee, 2007)

\begin{tabular}{lccc}
\hline & \multicolumn{3}{l}{ Fuzzy Linguistic Values } \\
\hline Linguistic Terms & $\mathrm{l}$ & $\mathrm{m}$ & $\mathrm{u}$ \\
\hline Very High Influence (VH) & 0.75 & 1.00 & 1.00 \\
High Influence (H) & 0.50 & 0.75 & 1.00 \\
Low Influence (L) & 0.25 & 0.50 & 0.75 \\
Very Low Influence (VL) & 0.00 & 0.25 & 0.50 \\
No Influence (NO) & 0.00 & 0.00 & 0.25 \\
\hline
\end{tabular}




\section{Step 2: Creating the direct-relation matrix}

Triangular fuzzy numbers introduced by Zadeh are used in generating the direct-relation matrix as presented in Equation (2).

$$
\tilde{Z}=\left[\begin{array}{cccc}
\tilde{Z}_{21} & 0 & 0 & \tilde{Z}_{2 n} \\
\cdot & \cdot & \cdot & \cdot \\
\tilde{Z}_{n 1} & \tilde{Z}_{n 2} & 0 & 0
\end{array}\right]
$$

Where $\tilde{Z}$ is direct relation matrix, $\tilde{Z}=\left(l_{i j}, m_{i j}, u_{i j}\right)$ and $i, j=1,2,3, . ., n$, here $\mathrm{i}$ and $\mathrm{j}$ represent criteria evaluated by DEMATEL

Step 3: Creating the normalized direct-relation matrix

$\tilde{T}=\lim _{k \rightarrow \infty}\left(\tilde{X^{1}}+\tilde{X^{2}} \ldots+\tilde{X^{k}}\right)=\tilde{X^{1}}+\tilde{X^{2}} \ldots+\tilde{X^{k}}=\tilde{X}(I-\tilde{X})^{-1}$

$\tilde{T}=\left[\begin{array}{cccccc}\tilde{t}_{11} & \tilde{t}_{12} & \cdot & \cdot & \cdot & \tilde{t}_{1 n} \\ \tilde{t}_{21} & \tilde{t}_{22} & \cdot & 0 & \cdot & \tilde{t}_{2 n} \\ \cdot & \cdot & \cdot & \cdot & \cdot & \cdot \\ \cdot & \cdot & \cdot & \cdot & \cdot & \cdot \\ \cdot & \cdot & \cdot & \cdot & \cdot & \cdot \\ \tilde{t}_{1 n} & \tilde{t}_{2 n} & \cdot & \cdot & \cdot & \tilde{t}_{n n}\end{array}\right]$

\section{Step 5: Implementing defuzzification}

The Total Relation Matrix is defuzzied by the Converting Fuzzy data into Crisp Scores (CFCS) method. The CFCS technique depends upon specifying the fuzzy max. and minimum of the fuzzy number range (Opricovic and Tzeng, 2003) and is more effective crisp values than the centroid method between Equation (8) and (15) (Wu and Lee, 2007; Opricovic and Tzeng, 2003). The total score is constituted as weighted average in terms of
The normalized direct relation matrix $(\tilde{X})$ is created like in Equation (5) by means of Equation (3) and (4).

$$
\begin{aligned}
& \tilde{X}_{i j}=\frac{\tilde{Z}_{i j}}{r}=\left(\frac{l_{i j}}{r}, \frac{m_{i j}}{r}, \frac{u_{i j}}{r}\right) \text { and } \\
& r_{i j}=\max _{1<i<n}\left(\sum_{j=1}^{n} u_{i j}\right) \\
& \tilde{X}=\left[\begin{array}{cccccc}
\tilde{X}_{11} & \tilde{X}_{12} & . & \cdot & \cdot & \tilde{X}_{1 n} \\
\tilde{X}_{21} & \tilde{X}_{22} & \cdot & 0 & \cdot & \tilde{X}_{2 n} \\
\cdot & \cdot & \cdot & & & \cdot \\
\cdot & \cdot & & \cdot & & \cdot \\
\cdot & \cdot & & & \cdot & \cdot \\
\tilde{X}_{1 n} & \tilde{X}_{2 n} & . & . & \cdot & \tilde{X}_{n n}
\end{array}\right]
\end{aligned}
$$

\section{Step 4: Computing fuzzy Total-relation matrix}

Total relation fuzzy matrix $(\tilde{T})$ is computed by means of Equation (6) as presented in Equation (7) (Lin and $\mathrm{Wu}, 2004$ ).

membership functions with the help of left and right scores in Equation 12 and 13 (Opricovic and Tzeng, 2003).

$A_{i j}^{k}=\left(l_{i j}^{k}, m_{i j}^{k}, u_{i j}^{k}\right)$ reveals fuzzy evaluations between criterion $i$ and criterion $j$ of the $k$ th power. Normalization is implemented:

$x l_{i j}^{k}=\left(l_{i j}^{k}-\min l_{i j}^{k}\right) / \Delta_{\min }^{\max }$ 
$x m_{i j}^{k}=\left(m_{i j}^{k}-\min m_{i j}^{k}\right) / \Delta_{\min }^{\max }$

$x u_{i j}^{k}=\left(u_{i j}^{k}-\min u_{i j}^{k}\right) / \Delta_{\min }^{\max }$

$\Delta_{\min }^{\max }=\max u_{i j}^{k}-\min l_{i j}^{k}$

Lower (left side-ls) and upper (right side-rs) normalized values are computed by using Equation (13) and (14)

$$
\begin{aligned}
& x l s_{i j}^{k}=x m_{i j}^{k} /\left(1+x m_{i j}^{k}-x l_{i j}^{k}\right) \\
& x u s_{i j}^{k}=x u_{i j}^{k} /\left(1+x u_{i j}^{k}-x m_{i j}^{k}\right)
\end{aligned}
$$

The total normalized crisp value is computed by Equation (14):

$x_{i j}^{k}=\left[x l s_{i j}^{k}\left(1-x l s_{i j}^{k}\right)+x u s_{i j}^{k} \cdot x u s_{i j}^{k}\right] /\left[1-x l s_{i j}^{k}+\right.$ $\left.x u s_{i j}^{k}\right]$

Finally, crisp value is computed by Equation (15)

$z_{i j}^{k}=\min l_{i j}^{k}+x_{i j}^{k} \cdot \Delta_{\min }^{\max }$

Step 6.Determining cause and effect factor groups

$D_{\dot{I}}$ is sum of the row as presented in Equation (16), $\tilde{R}_{i}$ is sum of the column as presented in Equation (17), $\tilde{D}_{i}+\tilde{R}_{i}$ reflect that selected perspective are related with other perspectives while $\tilde{D}_{i}-\widetilde{R}_{i}$ expresses whether selected perspective has effect on other perspectives.

$\tilde{D}_{i}=\left[\sum_{i=1} z_{i j}^{k}\right]_{n \times 1}=\left[z_{i j}^{k}\right]_{n \times 1}$

$\tilde{R}_{i}=\left[\sum_{i=1} z_{i j}^{k}\right]_{1 \times n}=\left[z_{i j}^{k}\right]_{1 \times n}$

Research and publication ethics were followed in this study.

\section{An Illustrative Example in Banking Sector}

The aim of study is to illustrate and to prove the significance of risk and agile perspectives for current BSC. Besides, it is displayed that risk and agile perspectives are related with current BSC perspectives.

Study is performed in banking sector. Banking sector is preferred as customer expectations change rapidly and banking sector reflects institutional. Evaluations were received from managers are used for fuzzy DEMATEL. Fuzzy DEMATEL is used to show whether risk and agile perspectives have a causal relationship with current four perspectives of BSC. For fuzzy DEMATEL, 24 managers working in banking industry are selected as decision-makers. Some characteristics of decision-makers are presented in Table 3. These managers performed pairwise comparisons in terms of fuzzy linguistic scale to illustrate that risk and agile perspectives are as significant as current four perspectives of BSC. Application steps of fuzzy DEMATEL are as follow.

Table 3

The Characteristics of decision-makers

\begin{tabular}{lcclcc}
\hline Gender & Number & $\%$ & Graduation Degree & Number & $\%$ \\
\hline Male & 19 & 79,2 & Bachelor's Degree & 11 & 45,8 \\
Female & 5 & 20,8 & Master Degree & 12 & 50,0 \\
Total & 24 & 100,0 & PHd Degree & 1 & 4,2 \\
& & & Total & 24 & 100,0 \\
Age & Number & $\%$ & & & \\
$31-35$ & 3 & 12,5 & Occupation & Number & $\%$ \\
$36-40$ & 14 & 58,3 & Computer Engineering & 14 & 58,3 \\
41 & 7 & 29,2 & Industrial Engineering & 8 & 33,3 \\
Total & 24 & 100 & Mathematics Engineering & 1 & 4,2 \\
& & & Management Engineering & 1 & 4,2 \\
Experience & Number & $\%$ & Total & 24 & 100,0 \\
5-10 years & 2 & 8,3 & & & \\
$11-15$ years & 12 & 50,0 & Position & Number & $\%$ \\
16- years & 10 & 41,7 & Service Manager & 19 & 79,2 \\
Total & 24 & 100,0 & Manager & 5 & 20,8 \\
& & & Total & 24 & 100,0 \\
\hline
\end{tabular}


Step 1: Determining criteria and generating fuzzy scale: Evaluation criteria are six perspectives of proposed BSC structure for this study. We used linguistic terms and triangular fuzzy numbers presented in Table 2 to make pairwise comparisons to measure relationships among six perspectives.

Step 2: Creating direct-relation matrix: Decisionmakers compared perspectives each other by using linguistic terms. These linguistic terms are converted into triangular fuzzy numbers. Since, 24 decision makers are included to the process, 24 decision matrixes are created. Table 4 presents average value of 24 experts' evaluations. Hence, Direct Relation Matrix is provided.

Table 4

The Direct Relation Matrix

\begin{tabular}{|c|c|c|c|c|c|c|c|c|c|c|c|c|c|c|c|c|c|c|}
\hline & \multicolumn{3}{|c|}{ P1 } & \multicolumn{3}{|c|}{ P2 } & \multicolumn{3}{|c|}{ P3 } & \multicolumn{3}{|c|}{ P4 } & \multicolumn{3}{|c|}{ P5 } & \multicolumn{3}{|c|}{ P6 } \\
\hline & l & $\mathrm{m}$ & $\mathrm{u}$ & l & $\mathrm{m}$ & $\mathrm{u}$ & l & $\mathrm{m}$ & $\mathrm{u}$ & l & $\mathrm{m}$ & $\mathrm{u}$ & l & $\mathrm{m}$ & $\mathrm{u}$ & l & $\mathrm{m}$ & $\mathrm{u}$ \\
\hline P1 & 0.00 & 0.00 & 0.00 & 0.28 & 0.53 & 0.78 & 0.29 & 0.54 & 0.79 & 0.08 & 0.33 & 0.58 & 0.48 & 0.73 & 0.91 & 0.38 & 0.63 & 0.88 \\
\hline P2 & 0.57 & 0.82 & 1.00 & 0.00 & 0.00 & 0.00 & 0.55 & 0.80 & 0.94 & 0.58 & 0.83 & 0.92 & 0.58 & 0.83 & 1.00 & 0.40 & 0.65 & 0.90 \\
\hline P3 & 0.45 & 0.70 & 0.91 & 0.59 & 0.84 & 1.00 & 0.00 & 0.00 & 0.00 & 0.64 & 0.89 & 0.95 & 0.57 & 0.82 & 0.92 & 0.42 & 0.67 & 0.92 \\
\hline P4 & 0.30 & 0.55 & 0.80 & 0.26 & 0.49 & 0.74 & 0.60 & 0.85 & 0.97 & 0.00 & 0.00 & 0.00 & 0.21 & 0.46 & 0.71 & 0.19 & 0.44 & 0.69 \\
\hline P5 & 0.70 & 0.95 & 1.00 & 0.67 & 0.92 & 1.00 & 0.54 & 0.79 & 1.00 & 0.53 & 0.78 & 0.94 & 0.00 & 0.00 & 0.00 & 0.60 & 0.85 & 0.99 \\
\hline P6 & 0.53 & 0.78 & 1.00 & 0.44 & 0.69 & 0.94 & 0.45 & 0.70 & 0.95 & 0.44 & 0.69 & 0.90 & 0.45 & 0.70 & 0.95 & 0.00 & 0.00 & 0.00 \\
\hline
\end{tabular}

Step 3: Creating the normalized direct-relation matrix: The normalized direct-relation matrix is obtained by dividing direct-relation matrix values to $r_{i j}$ value via Equation 8. $r_{i j}$ value is computed as 4.75 by (Equation 4). The normalized direct relation matrix is shown in Table 5.

Table 5

The Normalized Direct Relation Matrix

\begin{tabular}{|c|c|c|c|c|c|c|c|c|c|c|c|c|c|c|c|c|c|c|}
\hline & \multicolumn{3}{|c|}{ P1 } & \multicolumn{3}{|c|}{ P2 } & \multicolumn{3}{|c|}{ P3 } & \multicolumn{3}{|c|}{$\mathrm{P} 4$} & \multicolumn{3}{|c|}{ P5 } & \multicolumn{3}{|c|}{ P6 } \\
\hline & l & $\mathrm{m}$ & $\mathrm{u}$ & l & $\mathrm{m}$ & $\mathrm{u}$ & l & $\mathrm{m}$ & $\mathrm{u}$ & l & $\mathrm{m}$ & $\mathrm{u}$ & l & $\mathrm{m}$ & $\mathrm{u}$ & l & $\mathrm{m}$ & $\mathrm{u}$ \\
\hline \multirow{2}{*}{ P1 } & 0.0 & 0.0 & 0.0 & 0.0 & 0.1 & 0.1 & 0.0 & 0.1 & 0.1 & 0.0 & 0.0 & 0.1 & 0.1 & 0.1 & 0.1 & 0.0 & 0.1 & 0.1 \\
\hline & 0 & 0 & 0 & 6 & 1 & 6 & 6 & 1 & 6 & 2 & 7 & 2 & 0 & 5 & 8 & 8 & 3 & 8 \\
\hline \multirow{2}{*}{ P2 } & 0.1 & 0.1 & 0.2 & 0.0 & 0.0 & 0.0 & 0.1 & 0.1 & 0.1 & 0.1 & 0.1 & 0.1 & 0.1 & 0.1 & 0.2 & 0.0 & 0.1 & 0.1 \\
\hline & 2 & 7 & 0 & 0 & 0 & 0 & 1 & 6 & 9 & 2 & 7 & 9 & 2 & 7 & 0 & 8 & 3 & 8 \\
\hline \multirow{2}{*}{ P3 } & 0.0 & 0.1 & 0.1 & 0.1 & 0.1 & 0.2 & 0.0 & 0.0 & 0.0 & 0.1 & 0.1 & 0.1 & 0.1 & 0.1 & 0.1 & 0.0 & 0.1 & 0.1 \\
\hline & 9 & 4 & 8 & 2 & 7 & 0 & 0 & 0 & 0 & 3 & 8 & 9 & 2 & 7 & 9 & 8 & 4 & 9 \\
\hline \multirow{2}{*}{ P4 } & 0.0 & 0.1 & 0.1 & 0.0 & 0.1 & 0.1 & 0.1 & 0.1 & 0.2 & 0.0 & 0.0 & 0.0 & 0.0 & 0.0 & 0.1 & 0.0 & 0.0 & 0.1 \\
\hline & 6 & 1 & 6 & 5 & 0 & 5 & 2 & 7 & 0 & 0 & 0 & 0 & 4 & 9 & 4 & 4 & 9 & 4 \\
\hline \multirow{2}{*}{ P5 } & 0.1 & 0.1 & 0.2 & 0.1 & 0.1 & 0.2 & 0.1 & 0.1 & 0.2 & 0.1 & 0.1 & 0.1 & 0.0 & 0.0 & 0.0 & 0.1 & 0.1 & 0.2 \\
\hline & 4 & 9 & 0 & 4 & 9 & 0 & 1 & 6 & 0 & 1 & 6 & 9 & 0 & 0 & 0 & 2 & 7 & 0 \\
\hline \multirow{2}{*}{ P6 } & 0.1 & 0.1 & 0.2 & 0.0 & 0.1 & 0.1 & 0.0 & 0.1 & 0.1 & 0.0 & 0.1 & 0.1 & 0.0 & 0.1 & 0.1 & 0.0 & 0.0 & 0.0 \\
\hline & 1 & 6 & 0 & 9 & 4 & 9 & 9 & 4 & 9 & 9 & 4 & 8 & 9 & 4 & 9 & 0 & 0 & 0 \\
\hline
\end{tabular}

Step 4: Computing fuzzy the Total Relation

Matrix: The Total Relation Matrix is calculated by

Table 6

The Total Relation Matrix using Equation 10. The results are presented in Table 6.

\begin{tabular}{|c|c|c|c|c|c|c|c|c|c|c|c|c|c|c|c|c|c|c|}
\hline & \multicolumn{3}{|c|}{ P1 } & \multicolumn{3}{|c|}{ P2 } & \multicolumn{3}{|c|}{ P3 } & \multicolumn{3}{|c|}{$\mathrm{P} 4$} & \multicolumn{3}{|c|}{ P5 } & \multicolumn{3}{|c|}{ P6 } \\
\hline & l & $\mathrm{m}$ & $\mathrm{u}$ & l & $\mathrm{m}$ & $\mathrm{u}$ & l & $\mathrm{m}$ & $\mathrm{u}$ & l & $\mathrm{m}$ & $\mathrm{u}$ & l & $\mathrm{m}$ & $\mathrm{u}$ & l & $\mathrm{m}$ & $\mathrm{u}$ \\
\hline P1 & 0.06 & 0.28 & 1.48 & 0.11 & 0.36 & 1.55 & 0.11 & 0.37 & 1.60 & 0.07 & 0.32 & 1.47 & 0.14 & 0.39 & 1.58 & 0.12 & 0.36 & 1.54 \\
\hline P2 & 0.20 & 0.52 & 1.90 & 0.08 & 0.34 & 1.65 & 0.19 & 0.50 & 1.86 & 0.19 & 0.49 & 1.75 & 0.19 & 0.50 & 1.83 & 0.15 & 0.44 & 1.78 \\
\hline P3 & 0.18 & 0.50 & 1.86 & 0.19 & 0.49 & 1.80 & 0.09 & 0.36 & 1.69 & 0.20 & 0.50 & 1.73 & 0.19 & 0.49 & 1.80 & 0.15 & 0.44 & 1.76 \\
\hline P4 & 0.11 & 0.38 & 1.60 & 0.10 & 0.35 & 1.53 & 0.17 & 0.42 & 1.61 & 0.05 & 0.26 & 1.34 & 0.09 & 0.35 & 1.53 & 0.08 & 0.32 & 1.49 \\
\hline P5 & 0.23 & 0.56 & 1.95 & 0.21 & 0.53 & 1.87 & 0.20 & 0.53 & 1.93 & 0.19 & 0.51 & 1.80 & 0.10 & 0.38 & 1.71 & 0.19 & 0.50 & 1.84 \\
\hline P6 & 0.18 & 0.48 & 1.89 & 0.15 & 0.44 & 1.80 & 0.16 & 0.45 & 1.86 & 0.15 & 0.44 & 1.74 & 0.16 & 0.44 & 1.81 & 0.06 & 0.30 & 1.62 \\
\hline
\end{tabular}


Step 5: Implementing defuzzification: CFCS method is adopted for defuzzification. The Fuzzy Total Relation Matrix values are transformed to crisp values with the defuzzification process via Equations 12-19 as presented in Table 7 .

Step 6: Determining the cause and effect groups: In last step, $\mathrm{D}$ and $\mathrm{R}$ values are calculated and then values of $D+R$ and $D-R$ are obtained. The threshold value is determined for the network relationship map of the impacts. According to determined threshold value, results are visualized with the network relationship map of impacts. Firstly, $2^{\text {nd }}$ quartile value of (0.64) of all cells belonging to six perspectives is determined as the threshold value. Values and cells exceeding the threshold value are colored. Results according to the threshold value of 0.64 are presented in Table 7 .

Table 7

The Total-Relation Matrix Defuzzified With CFCS when the threshold value is 0.64

\begin{tabular}{ccccccccccc}
\hline & P1 & P2 & P3 & P4 & P5 & P6 & D & R & D+R & D-R \\
\hline P1 & 0.49 & 0.56 & 0.57 & 0.52 & 0.59 & 0.56 & 3.2756 & 3.9702 & 7.2458 & -0.695 \\
P2 & 0.73 & 0.56 & 0.71 & 0.69 & 0.70 & 0.65 & 4.0505 & 3.7483 & 7.7988 & 0.302 \\
P3 & 0.71 & 0.70 & 0.58 & 0.69 & 0.70 & 0.65 & 4.0302 & 3.9001 & 7.9303 & 0.13 \\
P4 & 0.58 & 0.54 & 0.61 & 0.44 & 0.54 & 0.52 & 3.2432 & 3.7032 & 6.9464 & -0.46 \\
P5 & 0.77 & 0.73 & 0.74 & 0.71 & 0.60 & 0.71 & 4.2591 & 3.7940 & 8.0531 & 0.465 \\
P6 & 0.70 & 0.66 & 0.68 & 0.65 & 0.66 & 0.52 & 3.8642 & 3.6070 & 7.4712 & 0.257 \\
\hline
\end{tabular}

If $\mathrm{D}+\mathrm{R}$ is high, it means that this perspective is more related with the other perspectives. If $D+R$ is low, it implies that this perspective is less related with the others. According to this, P5 (Risk) is perspective that has the most related with the others. P3 (Internal Business Process), P2 (Customer), P6 (Agile), P1 (Financial) and P4 (Learning and Growth) follow P5 in terms of significant respectively (Table 7).

If $D-R$ is positive, this perspective has a higher effect on the other perspectives. Then, this can be said as a cause perspective. If $D-R$ is negative, this perspective is affected by the other perspectives. This can be described as an effect perspective. When the outcomes are examined, P5 is perspective that has the highest effect on the other perspectives. P2, P6, P3 follow P5 in terms of significant respectively. Since P4 and P6 are negative values, they are effect perspectives (Table 7).

According to the threshold value of 0.64 which is determined by QUARTILE function of EXCEL., the relationship map of impacts is presented by Figure 5 . P2, P3, P5, P6 are in both cause and effect groups, while P1 and P4 are in only effect group for the threshold value of 0.64 . 


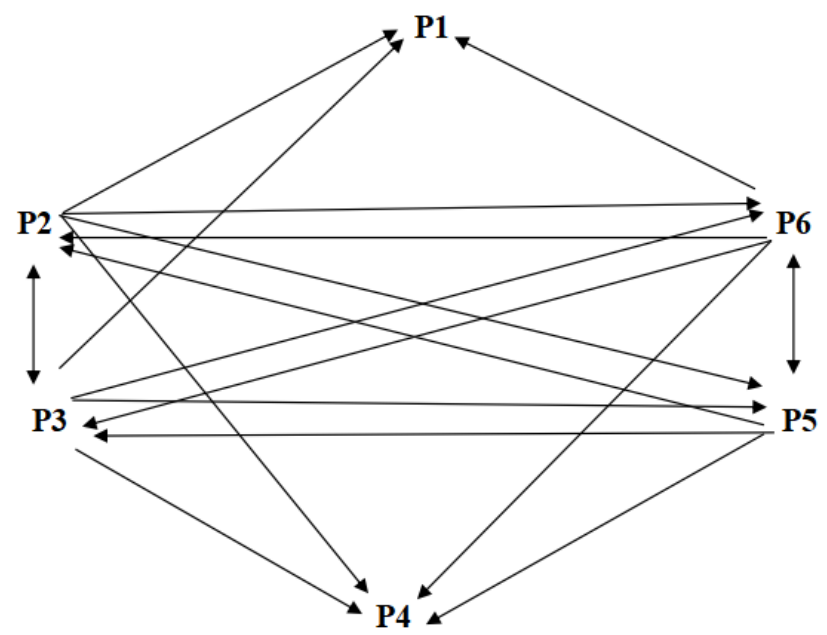

Figure 5. The network relationship map of impacts for the threshold value of 0,63

Secondly, the $3^{\text {rd }}$ quartile value of all cells is determined as second threshold value to explain whether causal relationships among perspectives are consistent or not. This value is calculated as 0.70 by QUARTILE function of EXCEL. Table 8 illustrates results of $3^{\text {rd }}$ quartile value $(0.70)$ which is determined as a threshold value. Values of cells exceeding the threshold value of 0.07 are colored with red.

Table 8

The Total-Relation Matrix Defuzzified With CFCS when the threshold value is 0.70

\begin{tabular}{lcccccccccc}
\hline & P1 & P2 & P3 & P4 & \multicolumn{1}{c}{ P5 } & P6 & D & \multicolumn{1}{c}{ R } & D+R & \multicolumn{1}{c}{ D-R } \\
\hline P1 & 0.49 & 0.56 & 0.57 & 0.52 & 0.59 & 0.56 & 3.2756 & 3.9702 & 7.2458 & -0.695 \\
P2 & 0.73 & 0.56 & 0.71 & 0.69 & 0.70 & 0.65 & 4.0505 & 3.7483 & 7.7988 & 0.302 \\
P3 & 0.71 & 0.70 & 0.58 & 0.69 & 0.70 & 0.65 & 4.0302 & 3.9001 & 7.9303 & 0.13 \\
P4 & 0.58 & 0.54 & 0.61 & 0.44 & 0.54 & 0.52 & 3.2432 & 3.7032 & 6.9464 & -0.46 \\
P5 & 0.77 & 0.73 & 0.74 & 0.71 & 0.60 & 0.71 & 4.2591 & 3.794 & 8.0531 & 0.465 \\
P6 & 0.70 & 0.66 & 0.68 & 0.65 & 0.66 & 0.52 & 3.8642 & 3.607 & 7.4712 & 0.257 \\
\hline
\end{tabular}

According to threshold value of 0.70 , network relationship map of impacts is presented in Figure 6. 


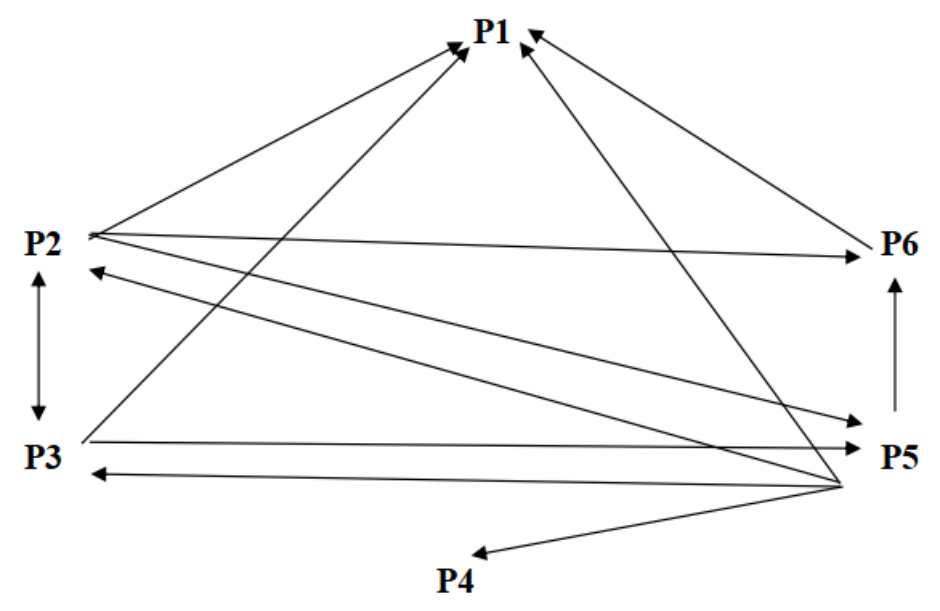

Figure 6. Network relationship map of impacts for threshold value of 0.70

When relationships are examined according to two threshold values in Figure 5 and Figure 6, similarities can be seen. Determined relationships in Table 6 and Table 7 for the threshold values of $2^{\text {nd }}$ quartile and $3^{\text {rd }}$ quartile show similar relationships. This means that causal relationships among the six perspectives are consistent.
Cause perspectives and effect perspectives can be observed through Cause and Effect Diagram. Figure 7 presents cause and effect diagram. P2, P3, P5, P6 are both cause and effect group, while P1 and P4 are only effect group for both threshold values.

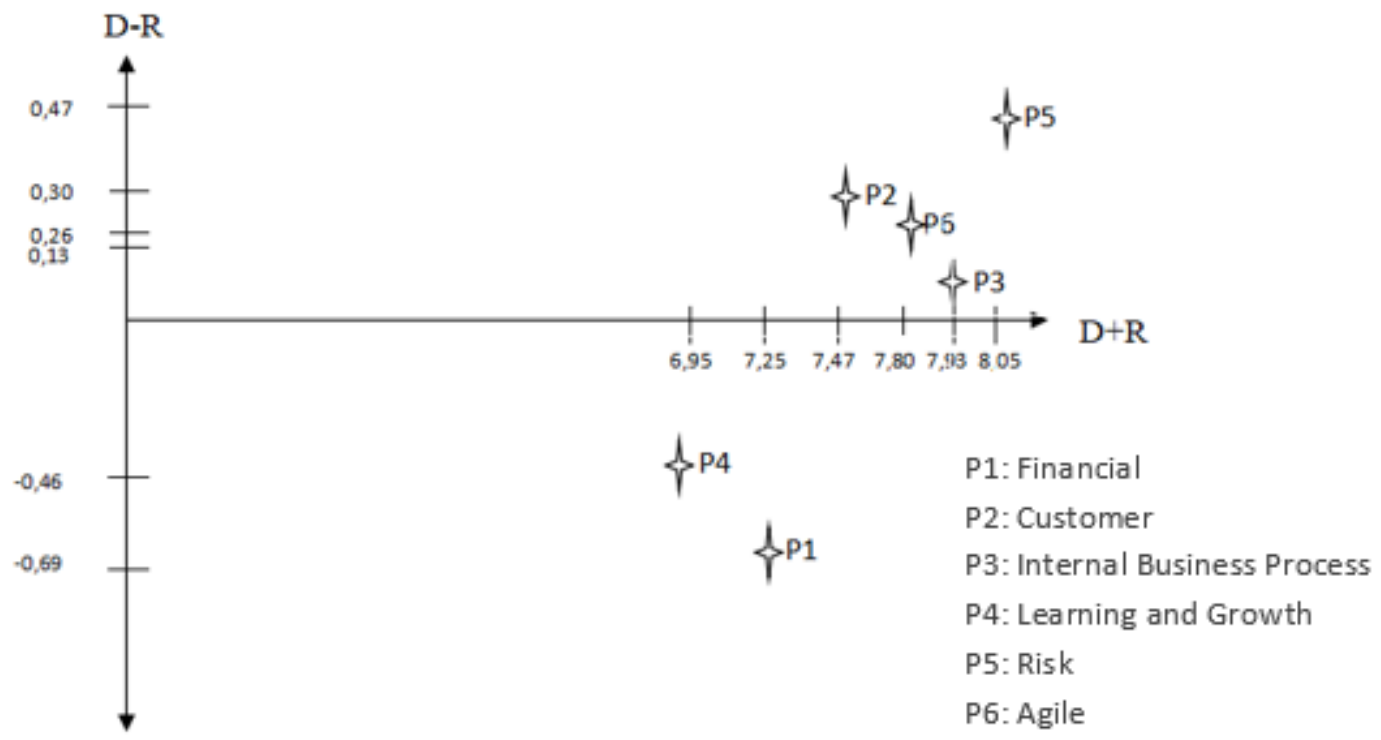

Figure 7. The Cause and Effect Diagram

The fuzzy DEMATEL results indicate that risk is the most related perspective with five perspectives. The Agile is in the fourth order after the internal business process $\left(2^{\text {nd }}\right)$ and customer $\left(3^{\text {rd }}\right)$. The financial and learning and growth follow these respectively. Similarly, risk is the most effective perspective in terms of other perspectives. The Agile is in the third order after customer. The Internal business process 
follows these. On the other hand, the financial and learning and growth perspectives are affected by the other perspectives. The financial perspective is the most affected perspective.

\section{Discussion and Conclusion}

In today's business environment the competition among companies is extremely advanced. It is necessary that companies should change themselves to become more innovative to prevent their rivals and manage the market. A firm which was in the market monopoly a few years ago might face with the dangers of bankruptcy nowadays. Therefore, it needs to keep up with agile and not to stay behind in the competition. For this, companies must use the external elements as well as the internal elements. Hence, it is insufficient to measure the non-financial parameters. The BSC is deficient as four perspectives, although the BSC covers the financial and non-financial measures. New perspectives (environmental, social, supplier and stakeholders etc.) have been added to BSC structure in the literature. Also new methods are integrated like SWOT analysis to tackle this problem as mentioned in the literature review. But the agile perspective is not added to the BSC so far. The Agile perspective brings about risks in the competitive marketplace. Companies should consider the potential risks in advance. Hence, banks must use the BSC's new model to evaluate their situation. This paper suggests six perspectives for the BSC.

To adapt rapidly and proactively their elements to unexpected and unpredicted environmental changes, banks should be agile. Therefore, their agility should be evaluated via agile perspective of BSC. Unexpected and unpredicted environmental changes bring risks. To cope with internal and external risks, situation of the banks should be evaluated via risk perspective of BSC. Adding risk and agile perspectives to current BSC structure, one of the deficiencies about BSC is tried to be dispelled by this study.

When we look at the BSC via viewpoint of SWOT analysis, while the traditional BSC evaluate internal structure of banks including the only Strengths (S) and Weaknesses (W) of SWOT analysis (S and W reflects the internal structure of firms), our proposed model contains external factors which banks face. The Agile perspective points out Opportunities (0) of SWOT, whereas the risk perspective signifies Threats (T) of SWOT. In this way, the new BSC embraces the external environment. The Risk and Agile perspectives reflect not only external elements but internal elements. Adding risk and agile perspectives provides opportunities and threats dimensions of SWOT analysis to integrate the BSC structure

This paper investigates whether the risk and agile perspectives are necessary for the BSC in banking industry. The relationships among perspectives are examined by the fuzzy DEMATEL. According to fuzzy DEMATEL results, risk and agile perspectives were among the cause factors. Both perspectives are related to current perspectives of BSC. Risk is the most related perspective with five perspectives while agile perspective is in the fourth order.

Furthermore, future researches can test the new BSC model in other sectors. Requirement of the risk and agile perspective for BSC can be evaluated for other industries. Six perspectives could be implemented in numerous sectors. The other Multiple Criteria Decision Making (MCDM) techniques like the ANP, AHP, TOPSIS could be applied when weighting the perspectives and their sub factors.

\section{Contributions of Authors}

In this study, Gülșen Akman created an idea for research, searched the literature, organized the study, wrote the manuscript, contributed to the editing and writing of the paper. Hakan Turan, created an idea for research, searched the literature, wrote the manuscript, applied the method, visualize the data, discussed the results and prepared manuscript formatting and editing.

\section{Conflict of Interest}

The authors declare no conflict of interest.

\section{References}

Ahn, H. (2001). Applying The Balanced Scorecard Concept:An Experience Report. Long Range Planning, $34 \quad$ (4), 441-461, Doi: https://doi.org/10.1016/S0024-6301(01) 0005-7

Akkoç, S., \& Vatansever, K. (2013). Fuzzy performance evaluation with AHP and Topsis methods: evidence from turkish banking sector after the global financial crisis. Eurasian Journal of Business and Economics, 6(11), 53-74. Retrieved from: https://www.ejbe.org/ 
EJBE2013Vol06No11p053AKKOCVATANSEVER.pdf

Aksakal, E., \& Dağdeviren, M. (2010). ANP ve DEMATEL Yöntemleri İle Personel Seçimi Problemine Bütünleşik bir Yaklaşım. Gazi Üniv. Müh. Mim. Fak. Dergisi, 25 (4), 905-913, Retrieved from: $\quad$ https://dergipark.org.tr/en/ download/article-file/75828

Al-Alawi, A.I. (2018). Using Balanced Scorecard In Measuring The Performance Of Online Banking: Cultivating Strategic Model Map In Financial Sector-Case Of Bahrain. The Journal of Internet Banking and Commerce, 23, 1-26, Retrieved from: https://www.icommercecentral.com/openaccess/using-balanced-scorecard-in-measuringthe-performance-of-online-banking-cultivatingstrategic-model-map-in-financial-sectorcaseof.php?aid $=87150$

Alidade, B., \& Ghasemi, M. (2015), Ranking the Branches of Bank Sepah of Sistan Baluchistan Using Balanced Score Card and Fuzzy MultiAttribute Decision Making Methods. Research Journal of Recent Sciences, 4(1), 17-24, Retrieved from: https://citeseerx.ist.psu.edu/viewdoc/ download?doi=10.1.1.1082.9521\&rep=rep1\&typ $\underline{e=p d f}$

Angel ,R., \& Rampersad, H. (2005). Why Do Scorecards Add Up? CA Magazine, 30-35, Retrieved from: https://www.researchgate.net/ publication/228643436 Do scorecards add up

Askarany, D. (2017). How Can We Improve the Balanced Scorecard? Global Journal of Technology \& Optimization, 7(3), 202, Doi: https://doi.org/10.4172/2229-8711.1000202

Asosheh, A., Nalchigar, S., \& Jamporazmey, M. (2010). Information technology Project evaluation: a integtrated data envelopment analysis and balanced scorecard approach. Expert Systems with Applications, 37, 5931- 5938. Doi: https://doi.org/10.1016/j.eswa.2010.02.012

Aryanezhad, M.B., Njafi, E., \& Farkoush, S.B. (2011). A BSC-DEA Approach to Measure The Relative Efficiency Of Service Industry: A Case Study of Banking Sector. International Journal of Industrial Engineering Computations, 2, 273-282, Doi: https://doi.org/10.5267/j.ijiec.2010.03.004

Awadallah, E.A., \& Allam, Q. A. (2015). A Critique of the Balanced Scorecard as a Performance Measurement Tool. International Journal of Business and Social Science, 6 (7), 91-99,
Retrieved

from:

https://ijbssnet.com/journals/

Vol 6 No 7 July 2015/9.pdf

Baykaşoğlu, A., Kaplanoğlu, V., Durmuşoğlu, Z., \& Şahin, C. (2013). Integrating Fuzzy DEMATEL and Fuzzy Hierarchical TOPSIS Methods for Truck Selection. Expert Systems with Applications. 40(3), 15, 899-907, Doi: https://doi.org/10.1016/j.eswa.2012.05.046

Beasley, J.E., Chen, A.L., Nunez, K., \& Wright, L. (2006). Working hand in hand: balanced scorecards and enterprise risk management. IMA's Annual Conference, 7 (3), 49-55.

Chang, S.-C., \& Tsai, P.-H. (2016). A Hybrıd Financial Performance Evaluation Model For Wealth Management Banks Following The Global Financial Crisis. Echnological And Economic Development Of Economy, 22(1), 21-46, Doi: https://doi.org/10.3846/20294913.2014.986 $\underline{771}$

Chen, J. K., \& Chen, S. (2010). Using a novel conjunctive MCDM approach based on DEMATEL, fuzzy ANP and TOPSIS as an innovation support system for Taiwanese higher education. Expert Systems with Applications, 37(3), 1981-1990, Doi: https://doi.org/10.1016/j.eswa.2009.06.079

Chen, T.Y., Chen, C.B., \& Peng, S.Y. (2008). Firm Operation Performance Analysis Using Data Envelopment Analysis and Balanced Scorecard: A Case Study of A Credit Cooperative Bank. International Journal of Productivity \& Performance Management, 57(7), 523-539, Doi: https://doi.org/10.1108/17410400810904010

Dave, S.R., \& Dave, S.R. (2012). Applying Balanced Scorecard in Indian Banking Sector: An Empirical Study of the State Bank of India. Pasific Business Review International, 5, 108120, Doi: https://doi.org/10.4018/978-1$\underline{\text { 5225-1837-2.ch036 }}$

Demir, C., \& Yllmaz, M.K. 2010. Stratejik Planlama Süreci ve Örgütler Açısından Önemi, Dokuz Eylül Üniversitesi Íktisadi ve İdari Bilimler Fakültesi, 25(1), 69-88, Retrieved from: https://dergipark.org.tr/tr/download/article$\underline{\text { file } / 211065}$

Dinçer , H., \& Hacıoğlu, U. (2013). Performance evaluation with fuzzy VIKOR and AHP method based on customer satisfaction in Turkish 
banking sector. Kybernetes, 42 (7), 1072-1085, Doi: https://doi.org/10.1108/K-02-2013-0021

Dinçer, H., Hacıŏlu, U., \& Yüksel, S. (2016). Balanced Scorecard-based Performance Assessment of Turkish Banking Sector with Analytic Network Process, Journal of Decision Sciences Applications, 1(1), 01-21, Retrieved from: https://scholar.google.com/scholar? cluster $=5180252697129934095 \& \mathrm{hl}=$ en $\&$ oi $=\mathrm{SC}$ holarr

Dinçer, H., \& Yüksel, S. (2019). An integrated stochastic fuzzy MCDM approach to the balanced scorecard-based service evaluation. Mathematics and Computers in Simulation, 166, 93-112, Doi: $\quad$ https://doi.org/10.1016/ j.matcom.2019.04.008

Dinçer, H., Yüksel, S., \& Martínez, L. (2019). Analysis of balanced scorecard-based SERVQUAL criteria based on hesitant decisionmaking approaches. Computers \& Industrial Engineering, 131, 1-12, Doi: https://doi.org/ $\underline{10.1016 / \text { i.cie.2019.03.026 }}$

Erbaşı, A., (2010). Stratejik Planlama Sürecinin Belediyelerde Uygulanmasına Yönelik Modelsel Bir Yaklaşım, Akademik Bakış Dergisi, 22, 1-14, Retrieved from: https://arastirmax.com/tr/system/ files/dergiler/9383/makaleler/22/arastirmaxstratejik-planlama-surecinin-belediyelerdeuygulanmasina-yonelik-modelsel-biryaklasim.pdf

Gabus, A., \& Fontela E. (1972). World Problems an Invitation To Further Thought Within The Framework of DEMATEL, Switzerland Geneva: Battelle Geneva Research Centre

Glykas, M. (2013). Fuzzy cognitive strategic maps in business process performance measurement. Expert Systems with Applications, 40(1), 1-14, Doi: https://doi.org/10.1016/i.eswa.2012.01.078

Hajikhani, A., \& Jafari, H.R. (2013). Developing A Mix Method of SWOT, BSC\&QFD Toward Strategic Planning. Interdisciplinary Journal of Contemporary Research In Business, 5 (1), 476489, Retrieved from: https://iournalarchieves32.webs.com/476-489.pdf

Hubbard, G. (2009). Measuring Organizational Performance: Beyond The Triple Bottom Line. Business Strategy and the Environment, 19, 177-191, Doi:https://doi.org/10.1002/bse.564
Hung, K. C., Julian, P., Chien, T., \& Jin, W. T. (2010). A decision support system for engineering design based on an enhanced fuzzy MCDM approach. Expert Systems with Applications, 37(1), 202213, Doi: https://doi.org/10.1016/i.eswa. $\underline{2009.04 .069}$

Jafari-Eskandari, M., Roudabr, N., \& Kamfiroozi, M. H. (2013). Banks' Performance Evaluation Model Based on The Balanced Score Card Approach, Fuzzy DEMATEL and Analytic Network Process. International Journal of Information. Security and Systems Management, 2(2), 191- 200, Retrieved from: https://www.sid.ir/en/Journal/ ViewPaper.aspx?ID=377141

Jeng, D.J-F. \& Tseng, G-H. (2012). Social influence on the use of Clinical Decision Support Systems: Revisitingthe Unified Theory of Acceptance and Use of Technology by the fuzzy DEMATEL technique. Computers \& Industrial Engineering, 62, 819-828,Doi: https://doi.org/10.1016/ j.cie.2011.12.016

Jin, Z., Deng, F., Li, H., \& Skitmore, M. (2013). Practical Framework for Measuring Performance of International Construction Firms. Journal of Construction Engineering and Management, 139 (9), 1154-1167, Retrieved from: https://ascelibrary.org/doi/full/ 10.1061/\%28ASCE\%29C0.1943$\underline{7862.0000718}$

Kannan, D., Jafarian, A., Khamene, H.A., \& Olfat, L. (2013). Competitive performance improvement by operational budget allocation using ANFIS and fuzzy quality function deployment: a case study. The International Journal of Advanced Manufacturing Technology, 68, 849-862, Doi: https://doi.org/10.1007/ $\underline{\text { s00170-013-4948-3 }}$

Kaplan, R.S., \& Norton, D.P. (1992).The Balanced Scorecard-Measures That Drive Performance.Harvard Business Review, 70(1), 61-66, Retrieved from: https://hbr.org/1992/01/the-balancedscorecard-measures-that-drive-performance-2

Kaplan, R., \& Norton, D. (1996). Using the Balanced Scorecard as a Strategic Management System. Harvard Business Review, 74(1), 75-85, Retrieved from: https://hbr.org/2007/07/ using-the-balanced-scorecard-as-a-strategicmanagement-system 
Kidd, P. T. (1994). Agile Manufacturing: Forging New Frontiers. Wokingham: Addison-Wesley

Lee, Y.C., Hu, H.Y., Yen, T.M., \& Tsai, C.H. (2008). Kano's and Decision Making Trial and Evaluation Laboratory Applied to Order Winners and Qualifiers Improvement: A Study of the Computer Industry, Information Technology Journal, 7(5), 702-714,Doi: https://doi.org/10.3923/itj.2008.702.714

Lin, C.-L., \& Wu, W.-W. (2004). A fuzzy extension of the DEMATEL method for group decision making, European Journal of Operational Research, 156, 445-455, Doi: https://doi.org/10.1016/j.eswa.2006.08.012

Liu, H.T. (2009). The Extension of Fuzzy QFD: From Product Planning to Part Deployment. Department of Industrial Engineering and Management. Expert Systems with Applications, 1(1), 1-57, Doi: https://doi.org/10.1016/ j.eswa.2009.02.070

Mahdian, S.M., Ghochani, S.M., Mahdian, S.A., \& Shojaei, M. (2012). Compilation Of Effective Strategy Based On SWOT and Evaluation On BSC Case Study:Dr. Abidi Co., Industrial Engineering Letters, 2 (7), 30-42, Retrieved from: $\quad$ https://www.iiste.org/Journals/ index.php/IEL/article/view/2730

Mandic, K., Delibasic, B., Knezevic, S., \& Benkovic, S. (2014). Analysis of the financial parameters of Serbian banks through the application of the fuzzy AHP and TOPSIS methods. Economic Modelling, 43, 30-37, Doi: https://doi.org/ 10.1016/j.econmod.2014.07.036

Möller, A., \& Schaltegger, S. (2005). The Sustainability Balanced Scorecard as a Framework for Eco-efficiency Analysis. Journal of Industrial Ecology, 9(4), 73-83, Doi: https://doi.org/10.1162/ 108819805775247927

Nezhad, M.B.A., Modiri, M., \& Yazdi, A.K. (2011). Using Multi-Attribute Decision Making For Designing Revised Balanced Scorecard In National Iranian Oil Products Distribution Company. Australian Journal of Basic and Applied Sciences, 5(8), 1151-1162, Retrieved from: $\quad$ http://www.ajbasweb.com/old/ ajbas/2011/August-2011/1151-1162.pdf

Nikolaou, I.E., \& Tsalis, T.A. (2013). Development of a sustainable balanced scorecard framework.
Ecological Indicators, 34,76-86, Doi: https://doi.org/10.1016/i.ecolind.2013.04.005

Noori, B. (2015). Prioritizing strategic business units in the face of innovation performance: Combining fuzzy AHP and BSC. International Journal of Business and Management, 3(1), 3656, Doi: https://doi.org/10.20472/ BM.2015.3.1.003

Oliveira, H.M.C. (2014). The balanced scorecard operating as a risk management tool. Review of Economic Studies and Research, VII (2), 41-57, Retrieved from: https://www.ceeol.com/ search/article-detail?id=208611

Opricovic, S., \& Tzeng, G. H. (2003). Defuzzification within a multicriteria decision model. International Journal of Uncertainty. Fuzziness and Knowledge-Based Systems, 11(5), 635-652, Doi: https://doi.org/10.1142/S0218488503002387

Owusu, A. (2017). Business intelligence systems and bank performance in Ghana: The balanced scorecard approach. Cogent Business \& Management, 4, 1364056 , Doi: https://doi.org/10.1080/23311975.2017.136 $\underline{4056}$

Penic, S., \& Dobrovic, Z. (2013). Application of SWOT and BSC In The Management Of Private Schools Of Higher Education, 1st International Virtual Scientific Conference, Zilina, Slovakia, 10-14 June 2013

Pettus, M.L. (2006). Utilizing Capabilities to Increase Stakeholder Wealth: A Balanced Scorecard Approach. Competition Forum, 4(1), 159-164, Retrieved from: https://search.proquest.com/ docview/214858767?pq-origsite $=$ gscholar\&fromopenview=true

Pickard, J. (2006). Scorecard System Might Not Be So Balanced, Says Research. People Management, 4, 14, Retrieved from: http://www.hcamag.com/hr-news/balancedscorecard-not-so-balanced-says-study225568.aspx

Rajab-Baigy, M., Foruzandeh, L. Mortazavi, M., \& Bigdeli, A. (2011). Strategy Map Creation Using A Balanced Scorecard Model Case Study: Central Bank of Iran. European Journal of Economics, Finance and Administrative Sciences, 36, 60-74, Retrieved from: https://sciexplore.ir/Documents/Details/610$\underline{\text { 045-394-838 }}$ 
Rdiouat, Y., Bahsani, S., Lakhdissi, M., \& Semma ,A. (2015). Measuring and Improving Information Systems Agility Through the Balanced Scorecard Approach. International Journal of Computer Science Issues, 12(5), 58-71, Retrieved from: http://www.ijcsi.org/papers/ IICSI-12-5-58-71.pdf

Rillo, M. (2004). Limitations Of Balanced Scorecard. Retrieved from: http://www.mattimar.ee/ publikatsioonid/ettevottemajandus/2004/12 Rillo.pdf (Assesing date: 18.06.2018)

Rostami, M., Goudarzi, A., \& Zaj, M.M. (2015). Defining Balanced Scorecard Aspects in Banking Industry Using FAHP Approach. International Journal of Economics and Business Administration, 1(1), 25-38, Retrieved from: http://www.aiscience.org/journal/allissues/ij eba.html?issueld=70220101

Salem, M. A., Hasnan, N., \& Osman, N.H. (2012). Balanced Scorecard: Weaknesses, Strengths, And Its Ability As Performance Management System Versus Other Performance Management Systems. Journal of Environment and Earth Science, 2 (9), 1-10, Retrieved from: https://iiste.org/Journals/ index.php/IEES/article/view/3043/3085

Sharifi, A.S., \& Mohammad Taleghani, M. (2011). Evaluation of intellectual Asset Performance by Balanced Score Cards Case Study: Bank Industry, In Central Bank of Iran. Australian Journal of Basic and Applied Sciences, 5(12), 316-320, Retrieved from: http://www.ajbasweb.com/old/ ajbas/2011/December-2011/316-320.pdf

Shaverdi, M. Akbari, M., \& Tafti, S.F. (2011). Combining Fuzzy MCDM with BSC Approach in Performance Evaluation of Iranian Private Banking Sector. Advances in Fuzzy Systems, 2011, Article ID 148712,1-12, Doi: https://doi.org/10.1155/2011/148712

Shieh, J.I., Wu, H.H., \& Huang, K.K. (2010). A DEMATEL method in identifying key success factors of hospital service quality. KnowledgeBased Systems, 23, 277-282, Doi: https://doi.org/10.1016/i.knosys.2010.01.013

Shih, K.H., Lin, C.W., \& Lin, B. (2011). Assessing the Quality Gap of Intellectual Capital In Banks. Total Quality Management, 22(3), 289-303, Doi: https://doi.org/10.1080/14783363.2010.530 $\underline{814}$

Spanò, R., Sarto, F., Caldarelli, A., \& Viganò, R. (2016). Innovation \& Performance Measurement: An Adapted Balanced Scorecard. International Journal of Business and Management, 11(6), 195-204, Doi: https://doi.org/10.5539/ijbm.v11n6p194

Steele, N.L., Branson, L., \& Sung, C.H., (2013). A Balanced Informational Diet: Can The Balanced Scorecard Act To Mitigate Hidden Profiles Effects? International Journal of Business \& Public Administration, 10(1), 75-86, Retrieved from: http://www.iabpad.com/category/ijbpav10-n1-2013/

Strack, R., \& Villis, U. (2002). RAVE ${ }^{\mathrm{TM}}$ :: Integrated Value Management for Customer, Human, Supplier and Invested Capital. European Management Journal, 20 (2), 147-158, Doi: https://doi.org/10.1016/S02632373(02)00025-7

Talathi, R. (2019). Balanced Score Card: Concept, Advantages and Limitations (With Diagram). Retrieved from: https://www.yourarticlelibrary.com/manage ment/controlling/balanced-score-cardconcept-advantages-and-limitations-withdiagram/69941

Tangen, S. (2003). An Overview of Frequently Used Performance Measures, Work Study, 52 (7), 347-354, Doi: https://doi.org/10.1108/ $\underline{00438020310502651}$

Thompson, K.R. \& Mathys, N.J. (2013). It's Time to Add the Employee Dimension to the Balanced Scorecard. Organizational Dynamics, 42, 135144, Retrieved from: https://www.econbiz.de/ Record/it-s-time-to-add-the-employeedimension-to-the-balanced-scorecardthompson-kenneth/10010119432

Tizroo, A., Esmaeili, A., Khaksar, E., Šaparauskas, J., \& Mozaffari, M.M. (2017). Proposing an agile strategy for a steel industry supply chain through the integration of balance scorecard and Interpretive Structural Modeling. Journal of Business Economics and Management, 18(2), 288-308, Doi: https://doi.org/10.3846/16111699.2017.127 $\underline{9683}$

Tseng, M. (2009). A causal and effect decision making model of service quality expectation 
using grey-Fuzzy DEMATEL approach. Expert Systems with Applications, 36(4), 7738-7748, Doi: https://doi.org/10.1016/j.eswa.2008.09.011

Turban, E., Leidner, D., McLean, E., \& Wetherbe, J. (2008). Information Technology for Management. (5th ed.), John Wiley and Sons, USA.

Wu, J., \& Haasis, H-D. (2013). Converting knowledge into sustainability performance of freight villages. Logistics Research, 6, 63-88, Doi: https://doi.org/10.1007/s12159-0130098-0

Wu, H.-Y. (2012). Constructing a strategy map for banking institutions with key performance indicators of the balanced scorecard. Evaluation and Program Planning, 35 (3), 303-320, Doi: https://doi.org/10.1016/i.evalprogplan.2011. $\underline{11.009}$

Wu, W.W., \& Lee, Y.T. (2007). Developing Global Managers' Competencies Using the Fuzzy DEMATEL Method. Expert Systems with Applications, 32, 499-507, Doi: https://doi.org/10.1016/j.eswa.2005.12.005

Wu, C.R., Lin, C.T., \& Tsai, P.H. (2010). Evaluating Business Performance of Wealth Management Banks. European Journal of Operational Research, 207(2), 971-979, Doi: https://doi.org/10.1016/j.ejor.2010.04.034

Yang, Y.P.O., Shieh, H.M., Leu, J.D., \& Tzeng, G.H. (2008). A Novel Hybrid MCDM Model Combined with DEMATEL and ANP with Applications. International Journal of Operations Research, 5(3), 160-168, Retrieved from: http://www.orstw.org.tw/ijor/vol5no3/paper -3-IJOR-vol5 3 -Yu-Ping Ou Yang.pdf

Yılmaz, G., \& İnel, M.N. (2018). Assessment of Sustainability Performances of Banks by TOPSIS Method and Balanced Scorecard Approach. International Journal of Business and Applied Social Science (IJBASS), 4 (1), 62-75, Retrieved from: https://www.ssoar.info/ ssoar/bitstream/

handle/document/55665/ssoar-ijbass-20181 -ylmaz et al-Assessment of sustainability performances of.pdf?sequence $=1$ 